\title{
2D Low-frequency Penetration of Elastic Waves Through a Double Periodic Array of Cracks
}

\section{D zemas frekvences elastīgo viḷ̣nu iekḷū̌šana caur dubultu periodisku plaisu masīvu}

\author{
Michael Remizov \\ Rostov-on-Don State University of Civil Engineering, Russia
}

\begin{abstract}
The paper is devoted to derivation of analytic expressions for coefficients of reflection and transmission when a plane wave interacts with a system of three identical twodimensional gratings, each of which consists of a periodic array of rectangular cracks of the elastic isotropic medium in 2-D. In a one-mode range approximation the problem is reduced to the system of hypersingular integral equations, solution of which gives the coefficients of reflection and propagation, and an explicit representation of the wave field inside the structure.
\end{abstract}

Keywords - Reflection and transmission coefficients, one-mode range approximation, two-dimensional grating, hipersingular integral equation.

\section{INTRODUCTION}

The penetration of elastic waves through a periodic lattice is an important problem in the field of ultrasound quantitative evaluation of materials, propagation of sound and electromagnetic waveguides, diaphragms. Various numerical methods have been applied in two-dimensional problems with periodic holes of arbitrary shape [1], [2], [7]. Despite the high accuracy of computer results, there are only a few analytical theories. In practice, analytical results can be obtained under the assumption of low frequencies and weak interaction of waves, where some approximate results can be set in an analytical form. Thus, analytical methods that provide explicit formulas for the corresponding scattering parameters specify only a certain low-frequency limit.

In [3] and [5] explicit analytical formulas were obtained for the parameters of reflection and transmission in one mode approximation to the acoustic wave penetrating through double-(triple)-periodic arrays of cracks and three-dimensional obstacles of arbitrary shape, as well as for the plane problems of wave propagation through periodic array of screens in elastic solids. The effect of viscosity on the reflection and transmission of acoustic waves on periodic lattice screens for 3-D problems were considered in [6].

The present study continues the discussion on the periodic structures in 2-D case. In the same way as in [1] - [6], we assume that with normal incidence of wave $e^{i k_{1} x}$ there is one mode of propagation, i.e. $a k_{2}<\pi$, where $k_{2}$ is the transverse wave number of the incident wave, and the condition $d / a>>1$ for the distance between the planes. The aim is the derivation of new analytical expressions for coefficients of reflection and transmission in the case of the two-dimensional distribution and description of new properties of solutions of the resulting system of hyper-singular integral equations, depending on the external parameters of the problem.

\section{MATHEMATICAL FORMULATION}

Consider a medium containing a doubly periodic structure, which consists of three infinite planes located at $x=0 ; d ; 2 d$ each of which contains an infinite periodic array of cracks, with a period $2 a$ along the axis $x$ with the opening between two adjacent cracks $2 b$ around $|y|=0 ; 2 a ; 4 a ; \ldots$. If we study the incidence of the plane wave on the grating along the positive direction of axis $x$, due to symmetry, we have to consider the waveguide width $2 a$ (Fig. 1). Lamé potentials are the following functions:

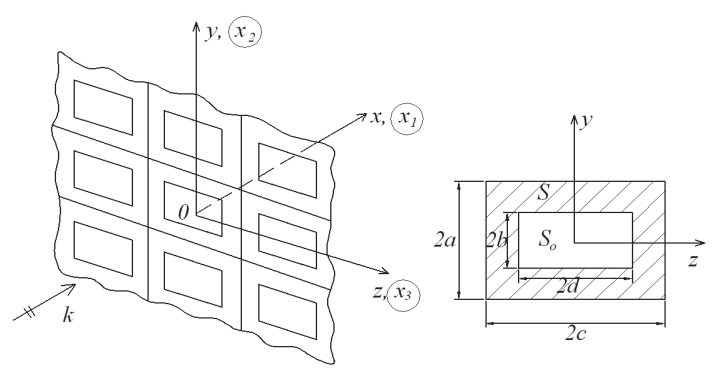

Fig. 1. A typical two-dimensional grating and a single cell.

$$
\begin{gathered}
\phi^{\text {left }}=e^{i k_{1} x}+R e^{-i k_{1} x}+\sum_{n=1}^{\infty} A_{n} e^{q_{n} x} \cos \left(\frac{\pi n y}{a}\right) ; \\
\psi^{\text {left }}=\sum_{n=1}^{\infty} B_{n} e^{r_{n} x} \sin \left(\frac{\pi n y}{a}\right), \quad x<0 ; \\
\varphi^{s}=e^{i k_{1} x}+F_{0}^{1} \cos \left[k_{1}\left(x-x_{s-1}\right)\right]+H_{0}^{1} \cos \left[k_{1}\left(x-x_{s}\right)\right]+ \\
+\sum_{n=1}^{\infty}\left\{F_{n}^{s} \operatorname{ch}\left[q_{n}\left(x-x_{s-1}\right)\right]+H_{n}^{s} \operatorname{ch}\left[q_{n}\left(x-x_{s}\right)\right]\right\} \cos \left(\frac{\pi n y}{a}\right) ; \\
\psi^{s}=\sum_{n=1}^{\infty}\left\{G_{n}^{s} \operatorname{ch}\left[r_{n}\left(x-x_{s-1}\right)\right]+P_{n}^{s} \operatorname{ch}\left[r_{n}\left(x-x_{s}\right)\right]\right\} \sin \left(\frac{\pi n y}{a}\right), \\
(s-1) d<x<s d, \quad s=1,2 ;
\end{gathered}
$$




$$
\begin{gathered}
\varphi^{\text {right }}=T e^{i k_{1}[x-2 d]}+\sum_{n=1}^{\infty} C_{n} e^{-q_{n}[x-2 d]} \cos \left(\frac{\pi n y}{a}\right) ; \\
\psi^{\text {right }}=\sum_{n=1}^{\infty} D_{n} e^{-r_{n}[x-2 d]} \sin \left(\frac{\pi n y}{a}\right) ; \quad x>2 d .
\end{gathered}
$$

All capital letters are some unknown constants and

$$
q_{n}=\left[(\pi n / a)^{2}-k_{1}^{2}\right]^{1 / 2}, r_{n}=\left[(\pi n / a)^{2}-k_{2}^{2}\right]^{1 / 2} \text {. }
$$

The time-harmonic dependence is taken as $e^{-i \omega t}, k_{1}$ and $k_{2}$ are the longitudinal and transverse wave numbers, $R$ and $T$ are the reflection and transmission coefficients, respectively.

The components of the stress tensor $\sigma_{x x}$ and $\sigma_{x y}$, the displacement components $u_{x}$ and $u_{y}$ can be expressed in terms of the Lamé wave potentials in the standard form.

In the considered structure, a longitudinal incident plane wave $e^{i k_{1} x}$ is entering from $-\infty$, rising to the scattered fields.

Accepting the continuity of the displacement field $u_{x}$, and $u_{y}$ outside the crack's domains at each vertical plane before the first screen $x<0$, among them $(s-1) D<x<s D, s=1,2$ and after the last one $x>2 D$, we introduce the following two unknown functions by

$$
\begin{aligned}
& g_{x}(y), g_{y}(y), \quad|y|<b: \\
& \bar{u}^{(\text {left })}-\bar{u}^{(1)}=\bar{g}^{1}(y) ; \quad x=0 ; \\
& \bar{u}^{(1)}-\bar{u}^{(2)}=\bar{g}^{2}(y) ; \quad x=d ; \\
& \bar{u}^{(2)}-\bar{u}^{\text {(right) }}=\bar{g}^{3}(y) ; \quad x=2 d .
\end{aligned}
$$

Now (1-3) can be used to represent the expressions for all constants appearing in potentials in (1) in terms of $g_{x}(y), g_{y}(y)$. By integration of equations (3) over the domains of the openings $|y|<b$, one obtains

$$
\begin{aligned}
& -i k_{1} R-H_{0}^{1} k_{1} \sin \left(k_{1} d\right)=\frac{1}{2 a} \int_{-a}^{a} g_{x}^{1}(y) \mathrm{d} y \\
& -F_{0}^{1} k_{1} \sin \left(k_{1} d\right)-H_{0}^{2} k_{1} \sin \left(k_{1} d\right)=\frac{1}{2 a} \int_{-a}^{a} g_{x}^{2}(y) \mathrm{d} y ; \\
& -F_{0}^{2} k_{1} \sin \left(k_{1} d\right)+i k_{1} e^{i k_{1} 2 d}-i k_{1} T=\frac{1}{2 a} \int_{-a}^{a} g_{x}^{3}(y) \mathrm{d} y .
\end{aligned}
$$

The orthogonality of the trigonometric functions with the assumption $q_{n} d \approx \pi n d / a \gg 1, \quad n=1,2,3, \ldots$, reduces (3) to the following relations, connecting the rest 12 coefficients:

$$
\begin{gathered}
{\left[A_{n}+H_{n}^{1} \operatorname{sh}\left(q_{n} d\right)\right] q_{n}+\left[B_{n}-P_{n}^{1} \operatorname{ch}\left(r_{n} d\right) D_{n j}^{(3)}\right] \frac{\pi n}{a}=} \\
=\frac{1}{2 a} \int_{-a}^{a} g_{x}^{1}(y) \cos \left(\frac{\pi n y}{a}\right) \mathrm{d} y \\
{\left[-A_{n}+H_{n}^{1} \operatorname{ch}\left(q_{n} d\right)\right] \frac{\pi n}{a}-\left[B_{n}+P_{n}^{1} \operatorname{sh}\left(r_{n} d\right)\right] r_{n}=}
\end{gathered}
$$

$$
\begin{gathered}
=\frac{1}{2 a} \int_{-a}^{a} g_{y}^{1}(y) \sin \left(\frac{\pi n y}{a}\right) \mathrm{d} y \\
{\left[F_{n}^{1}+H_{n}^{2}\right] q_{n} \operatorname{sh}\left(q_{n} d\right)+\left[G_{n}^{1}-P_{n}^{2}\right] \frac{\pi n}{a} \operatorname{ch}\left(r_{n} d\right)=} \\
=\frac{1}{2 a} \int_{-a}^{a} g_{x}^{2}(y) \cos \left(\frac{\pi n y}{a}\right) \mathrm{d} y ; \\
{\left[-F_{n}^{1}+H_{n}^{2}\right] \frac{\pi n}{a} \operatorname{ch}\left(q_{n} d\right)-\left[G_{n}^{1}+P_{n}^{2}\right] r_{n} \operatorname{sh}\left(r_{n} d\right)=} \\
=\frac{1}{2 a} \int_{-a}^{a} g_{y}^{2}(y) \sin \left(\frac{\pi n y}{a}\right) d y ; \\
{\left[F_{n}^{2} \operatorname{sh}\left(q_{n} d\right)+C_{n}\right] q_{n}-\left[G_{n}^{2} \operatorname{ch}\left(r_{n} d\right)-D_{n}\right] \frac{\pi n}{a}=} \\
=\frac{1}{2 a} \int_{-a}^{a} g_{x}^{3}(y) \cos \left(\frac{\pi n y}{a}\right) \mathrm{d} y ; \\
{\left[-F_{n}^{2} \operatorname{ch}\left(q_{n} d\right)+C_{n}\right] \frac{\pi n}{a}-\left[G_{n}^{2} \operatorname{sh}\left(r_{n} d\right)+D_{n}\right] r_{n}=}
\end{gathered}
$$

The continuity assumption for the stress fields out of cracks over each plane is the following:

$$
\begin{aligned}
& \sigma_{x x}^{(\text {left })}=\sigma_{x x}^{(1)} ; \sigma_{x y}^{(l e f t)}=\sigma_{x y}^{(1)}, x=0 ; \\
& \sigma_{x x}^{(1)}=\sigma_{x x}^{(2)} ; \sigma_{x y}^{(1)}=\sigma_{x y}^{(2)}, x=d ; \\
& \sigma_{x x}^{(2)}=\sigma_{x x}^{(\text {right })} ; \sigma_{x y}^{(2)}=\sigma_{x y}^{(\text {right })}, x=2 d .
\end{aligned}
$$

After applying the same procedure of integration over the same segment $|y|<b$ for (6) and taking into account the orthogonality property of trigonometric functions, the remaining 9 ratios will be obtained, which together with (4) and (5) form an algebraic system with 18 unknown constants. The solution of equations of the system for $x=0$ defines the appropriate constants $P_{n}^{1}, A_{n}, B_{n}, H_{n}^{1}, F_{0}^{1}, H_{0}^{1}, R$, expressions for which are used in the following form:

$$
\begin{gathered}
F_{0}^{1}=\frac{e^{i k_{1} d}}{4 a k_{1} \sin \left(k_{1} d\right)} \int_{-a}^{a} g_{x}^{1}(\eta) \mathrm{d} \eta-\frac{1}{4 a k_{1} \sin \left(k_{1} d\right)} \int_{-a}^{a} g_{x}^{2}(\eta) \mathrm{d} \eta- \\
-\frac{e^{i k_{1} d}}{4 a k_{1} \sin \left(k_{1} d\right)} \int_{-a}^{a} g_{x}^{3}(\eta) \mathrm{d} \eta \\
H_{0}^{1}=-\frac{1}{4 a k_{1} \sin \left(k_{1} d\right)} \int_{-a}^{a} g_{x}^{1}(\eta) \mathrm{d} \eta+\frac{e^{i k_{1} d}}{4 a k_{1} \sin \left(k_{1} d\right)} \int_{-a}^{a} g_{x}^{2}(\eta) \mathrm{d} \eta+ \\
+\frac{e^{i k_{1} 2 d}}{4 a k_{1} \sin \left(k_{1} d\right)} \int_{-a}^{a} g_{x}^{3}(\eta) \mathrm{d} \eta
\end{gathered}
$$




$$
\begin{aligned}
& R=-\frac{1}{4 a k_{1} i} \int_{-a}^{a} g_{x}^{1}(\eta) \mathrm{d} \eta-\frac{e^{i k_{1} d}}{4 a k_{1} i} \int_{-a}^{a} g_{x}^{2}(\eta) \mathrm{d} \eta- \\
& -\frac{e^{i k_{1} 2 d}}{4 a k_{1} i} \int_{-a}^{a} g_{x}^{3}(\eta) \mathrm{d} \eta \\
& H_{n}^{1}=\frac{1}{2 a \operatorname{sh}\left(q_{n} d\right)}\left[-\frac{r_{n j}^{2}+a_{n}^{2}}{q_{n} k_{2}^{2}} \int_{-a}^{a} g_{x}^{1}(\eta) \cos \left(\frac{\pi n \eta}{a}\right) \mathrm{d} \eta+\right. \\
& \left.+\frac{2 a_{n}}{k_{2}^{2}} \int_{-a}^{a} g_{y}^{1}(\eta) \sin \left(\frac{\pi n \eta}{a}\right) \mathrm{d} \eta\right] \\
& A_{n}=\frac{1}{2 a}\left[-\frac{r_{n j}^{2}+a_{n}^{2}}{q_{n} k_{2}^{2}} \int_{-a}^{a} g_{x}^{1}(\eta) \cos \left(\frac{\pi n \eta}{a}\right) \mathrm{d} \eta-\right. \\
& \left.-\frac{2 a_{n}}{k_{2}^{2}} \int_{-a}^{a} g_{y}^{1}(\eta) \sin \left(\frac{\pi n \eta}{a}\right) \mathrm{d} \eta\right] \\
& B_{n}=\frac{1}{2 a}\left[\frac{2 a_{n}}{k_{2}^{2}} \int_{-a}^{a} g_{x}^{1}(\eta) \cos \left(\frac{\pi n \eta}{a}\right) \mathrm{d} \eta-\right. \\
& \left.-\frac{\gamma_{0}}{c_{1}^{2} r_{n} k_{1}^{2}} \int_{-a}^{a} g_{y}^{1}(\eta) \sin \left(\frac{\pi n \eta}{a}\right) \mathrm{d} \eta\right] \\
& P_{n}^{1}=\frac{1}{2 a \operatorname{sh}\left(q_{n} d\right)}\left[-\frac{2 a_{n}}{k_{2}^{2}} \int_{-a}^{a} g_{x}^{1}(\eta) \cos \left(\frac{\pi n \eta}{a}\right) \mathrm{d} \eta-\right. \\
& \left.-\frac{\gamma_{0}}{c_{1}^{2} r_{n} k_{1}^{2}} \int_{-a}^{a} g_{y}^{1}(\eta) \sin \left(\frac{\pi n \eta}{a}\right) \mathrm{d} \eta\right] \text {. }
\end{aligned}
$$

Formulas for the other constants for the sake of brevity where omitted.

Now, the obtained unknown constants are used to satisfy the condition of equality to zero of the component stresses (2.7) on the crack. Here we must take into account that the problem remain the only non-trivial functions $g_{x}^{s}(y) ;|y|<b ; s=1,2,3$ included in the ratio

$$
\begin{aligned}
& \sigma_{x x}^{(\text {left })}=\sigma_{x x}^{(1)}=0, \quad x=0 ; \\
& \sigma_{x x}^{(1)}=\sigma_{x x}^{(2)}=0, \quad x=d ; \\
& \sigma_{x x}^{(2)}=\sigma_{x x}^{(\text {right })}=0, \quad x=2 d .
\end{aligned}
$$

Thus, omitting some intermediate mathematical conversions, one obtains the following system of integral equations with respect to these functions:

$-\frac{1}{2 a} \int_{-a}^{a} K(y-t) g_{x}^{1}(t) \mathrm{d} t+\frac{e^{i k_{1} d}}{4 a k_{1} i} \int_{-a}^{a} g_{x}^{2}(t) \mathrm{d} t+\frac{e^{i k_{1} 2 d}}{4 a k_{1} i} \int_{-a}^{a} g_{x}^{3}(t) \mathrm{d} t=1 ;$

$\frac{e^{i k_{1} d}}{4 a k_{1} i} \int_{-a}^{a} g_{x}^{1}(t) \mathrm{d} t-\frac{1}{2 a} \int_{-a}^{a} K(y-t) g_{x}^{2}(t) \mathrm{d} t+\frac{e^{i k_{1} d}}{4 a k_{1} i} \int_{-a}^{a} g_{x}^{3}(t) \mathrm{d} t=e^{i k_{1} d}$ $\frac{e^{i k_{1} 2 d}}{4 a k_{1} i} \int_{-a}^{a} g_{x}^{2}(t) \mathrm{d} t+\frac{e^{i k_{1} d}}{4 a k_{1} i} \int_{-a}^{a} g_{x}^{2}(t) \mathrm{d} t-\frac{1}{2 a} \int_{-a}^{a} K(y-t) g_{x}^{3}(t) \mathrm{d} t=e^{i k_{1} 2 d}$

where

$$
K(y)=i / 2 k_{1}+\sum_{n=1}^{\infty} \frac{R_{n}}{q_{n} k_{2}^{2}} \cos \left(\frac{\pi n y}{a}\right), \quad R_{n}=\left[2 a_{n}^{2}-k_{2}^{2}\right]^{2}-4 r_{n} q_{n} a_{n}^{2} .
$$

\section{PROPERTIES OF INTEGRAL EQUATIONS}

Similarly as in [4], let us consider the auxiliary equation $(|y|<b)$ :

$$
\begin{aligned}
& \frac{1}{2 a} \int_{-b}^{b} h(\eta) K(y-\eta) \mathrm{d} \eta=1 ; \\
& K(y)=\sum_{n=1}^{\infty} L_{n} \cos \left(a_{n} y\right) ; \quad L_{n}=\frac{R_{n}}{k_{2}^{2} q_{n}} .
\end{aligned}
$$

Note, that $L_{n} \approx-2\left[1-\frac{c_{2}^{2}}{c_{1}^{2}}\right] a_{n}, n \rightarrow \infty$. Then the sum, consisting of the kernel turns to the form

$$
\begin{gathered}
K(y)=-2\left[1-\frac{c_{2}^{2}}{c_{1}^{2}}\right] \sum_{n=1}^{\infty} a_{n} \cos \left(a_{n} y\right)+\sum_{n=1}^{\infty}\left(L_{n}+2\left[1-\frac{c_{2}^{2}}{c_{1}^{2}}\right]\right) a_{n} \cos \left(a_{n} y\right), \\
K(y)=-2\left[1-\frac{c_{2}^{2}}{c_{1}^{2}}\right] I(y)+K_{r}(y) .
\end{gathered}
$$

Now the second sum is some regular function. The first one has both the regular and the singular parts: $I(y)=\left[I_{r}(y)+I_{s}(y)\right]$.

Putting $\tilde{y}=(y-\eta) / a$ and then omittig tilde, we get

$$
\frac{a}{\pi} I(y)=\sum_{n=1}^{\infty} n \cos (\pi n y)
$$

Using the generalized form for the sum [10],

$$
\begin{gathered}
\sum_{n=1}^{\infty} n \cos (\pi n y)=\lim _{\varepsilon \rightarrow+0} \sum_{n=1}^{\infty} e^{-\varepsilon n} n \cos (\pi n y)=\frac{1}{4 \sin ^{2}(\pi y / 2),} \\
\left(\approx-\frac{1}{\pi^{2} y^{2}}, y \rightarrow 0\right),
\end{gathered}
$$

one obtains the kernel of the integral equation (10)

$$
K(y)=-2\left[1-\frac{c_{2}^{2}}{c_{1}^{2}}\right]\left(I_{r}(y)+I_{s}(y)\right)+K_{r}(y)
$$

whith regular and singular parts

$$
\frac{a}{\pi} I_{r}(y)=\frac{1}{\pi^{2} y^{2}}-\frac{1}{4 \sin ^{2}(\pi y / 2)}, \frac{a}{\pi} I_{s}(y)=-\frac{1}{\pi^{2} y^{2}} .
$$

One can see that the obtained singular behaviour of the kernel for small arguments contains a 1D hyper-singular term, well known in the linear elasticity theory for cracks in 
unbounded media [7], [9]. In order to provide the stability of the numerical treatment, in the performed numerical experiments the discrete quadrature formulas are applied for 1D hyper-singular kernels, known as a "method of discrete vortices" [8]. Using the new presentation for the kernel of the basic dual integral equation (22), one rewrites it in the following form:

$$
\begin{gathered}
\frac{1}{2 a} \int_{-b}^{b} h(\eta)\left[\Phi_{r}(y-\eta)+\frac{2 a\left[1-\frac{c_{2}^{2}}{c_{1}^{2}}\right]}{\pi(y-\eta)^{2}}\right] \mathrm{d} \eta=1, \\
\Phi_{r}(y)=-2\left[1-\frac{c_{2}^{2}}{c_{1}^{2}}\right] I_{r}(y)+K_{r}(y) .
\end{gathered}
$$

The discretisation of the integral ratio leads to following formula

$$
\begin{gathered}
\frac{1}{2 a} \sum_{k=1}^{N} \int_{\eta_{k-1}}^{\eta_{k}} h(\eta)\left[\Phi_{r}\left(y_{l}-\eta\right)+\frac{2 a\left[1-\frac{c_{2}^{2}}{c_{1}^{2}}\right]}{\pi\left(y_{l}-\eta\right)^{2}}\right] \mathrm{d} \eta= \\
\frac{1}{2 a} \sum_{k=1}^{N} h\left(\eta_{k}\right) \int_{\eta_{k-1}}^{\eta_{k}} h(\eta)\left[\Phi_{r}\left(y_{l}-\eta_{k}\right) \varepsilon_{1}+\frac{2 a\left[1-\frac{c_{2}^{2}}{c_{1}^{2}}\right]}{\pi\left(y_{l}-\eta\right)^{2}} \mathrm{~d}\left(\eta-y_{l}\right)\right]= \\
=\frac{1}{2 a} \sum_{k=1}^{N} h\left(\eta_{k}\right)\left[\Phi_{r}\left(y_{l}-\eta_{k}\right) \varepsilon_{1}-\frac{2 a\left[1-\frac{c_{2}^{2}}{c_{1}^{2}}\right]}{\pi\left(y_{l}-\eta_{k}\right)}+\frac{2 a\left[1-\frac{c_{2}^{2}}{c_{1}^{2}}\right]}{\pi\left(y_{l}-\eta_{k-1}\right)}\right],
\end{gathered}
$$

where $\eta_{k}=-b+k \varepsilon_{1}, \quad y_{l}=-b+(l-0.5) \varepsilon_{1}$,

$$
l=1, \ldots, N, \quad \varepsilon_{1}=2 b / N \text {. }
$$

Finally we have the system of algebraic equations:

$$
\frac{1}{2 a} \sum_{k=1}^{N} h\left(\eta_{k}\right)\left[\Phi_{r}\left(y_{l}-\eta_{k}\right) \varepsilon_{1}-\frac{2 a\left[1-\frac{c_{2}^{2}}{c_{1}^{2}}\right]}{\pi}\left(\frac{1}{\left(y_{l}-\eta_{k}\right)}-\frac{1}{\left(y_{l}-\eta_{k-1}\right)}\right)\right]=1 .
$$

\section{EXPLICIT FORMULAS FOR THE WAVE CHARACTERISTICS}

Similarly to [3], let us consider the auxiliary equation and set

$$
\frac{1}{2 a} \int_{-a}^{a} h(\eta) \sum_{n=1}^{\infty} \frac{R_{n}}{k_{2}^{2} q_{n}} \cos \left[a_{n}(y-t)\right] \mathrm{d} t=1, \quad H=\int_{-a}^{a} h(t) \mathrm{d} t .
$$

In terms of the even function $h(y)$, we deduce from (19):

$$
\begin{aligned}
& k_{2}^{-2} g_{x}^{1}(\eta)=h(\eta)\left\{\left(1 / 4 a i k_{1}\right) J_{1}+\frac{e^{i k_{1} d}}{4 a i k_{1}} J_{2}+\frac{e^{i k_{1} 2 d}}{4 a i k_{1}} J_{3}-1\right\} \\
& k_{2}^{-2} g_{x}^{2}(\eta)=h(\eta)\left\{\left(1 / 4 a i k_{1}\right) J_{2}+\frac{e^{i k_{1} d}}{4 a i k_{1}}\left[J_{1}+J_{3}\right]-e^{i k_{1} d}\right\} ;(20) \\
& k_{2}^{-2} g_{x}^{3}(\eta)=h(\eta)\left\{\left(1 / 4 a i k_{1}\right) J_{3}+\frac{e^{i k_{1} d}}{4 a i k_{1}} J_{2}+\frac{e^{i k_{1} 2 d}}{4 a i k_{1}} J_{1}-e^{i k_{1} 2 d}\right\}
\end{aligned}
$$

Here we put

$$
J_{j}=\int_{-a}^{a} g_{x}^{j}(t) \mathrm{d} t, j=1,2,3
$$

By integrating (20) over $|y|<b$ one obtains the system of linear algebraic equations for the unknown $J_{j}, j=1,2,3$.

$$
\begin{aligned}
& \left(k_{2}^{-2}-\tilde{H}\right) J_{1}-\left(\tilde{H} e^{i k_{1} d}\right) J_{2}-\left(e^{i k_{1} 2 d} \tilde{H}\right) J_{3}=-H \\
& -\left(\tilde{H} e^{i k_{1} d}\right) J_{1}+\left(k_{2}^{-2}-\tilde{H}\right) J_{2}-\left(e^{i k_{1} d} \tilde{H}\right) J_{3}=-H e^{i k_{1} d} ; \\
& -\left(\tilde{H} e^{i k_{1} d}\right) J_{1}-\left(e^{i k_{1} d} \tilde{H}\right) J_{2}+\left(k_{2}^{-2}-\tilde{H}\right) J_{3}=-H e^{i k_{1} 2 d}
\end{aligned}
$$

where $\widetilde{H}=H / 4 a i k_{1}$. Therefore, so far as the auxiliary equation (10) is solved and $h(y)$ is obtained, all necessary characteristics of the wave field can be found. Thus, the reflection and the transmission coefficient can be obtained as follows:

$$
\begin{gathered}
R=-\frac{1}{4 a i k_{1}} \int_{-a}^{a} g_{x}^{1}(t) \mathrm{d} t-\frac{e^{i k_{1} d}}{4 a i k_{1}} \int_{-a}^{a} g_{x}^{2}(t) \mathrm{d} t- \\
-\frac{e^{i k_{1} 2 d}}{4 a i k_{1}} \int_{-a}^{a} g_{x}^{3}(t) \mathrm{d} t \\
T=-\frac{e^{i k_{1} 2 d}}{4 a i k_{1}} \int_{-a}^{a} g_{x}^{1}(t) \mathrm{d} t-\frac{e^{i k_{1} d}}{4 a i k_{1}} \int_{-a}^{a} g_{x}^{2}(t) \mathrm{d} t- \\
-\frac{1}{4 a i k_{1}} \int_{-a}^{a} g_{x}^{3}(t) \mathrm{d} t+e^{i k_{1} 2 d}
\end{gathered}
$$

\section{NUMERICAL RESULTS}

We obtained explicit expressions for the scattering parameters which completes the application of this analytical approach in low frequency regime. Some examples of their behaviour depending on the frequency and size of cracks in elastic media with the ratio for the elastic velocities $c_{1} / c_{2}=1.826$ are shown in Fig. 2 - Fig. 4 .

Module transmission coefficient $|T|$ always decreases with oscillations with increasing frequency regardless of the geometry of the lattice. Oscillating mode and at the same time a certain loss of the passage is evident with increasing relative aperture of the crack (Fig. 2). 
$|T|$

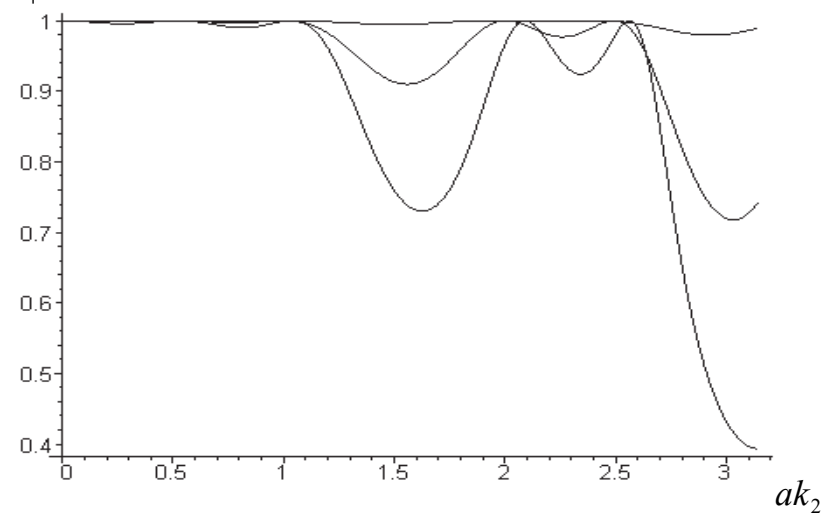

Fig. 2. The transmission coefficient versus frequency parameter.

A larger setting of $D$ for any size of the crack leads to a frequency dependence with a more frequent nature of oscillations (Fig. 3).

$|T|$

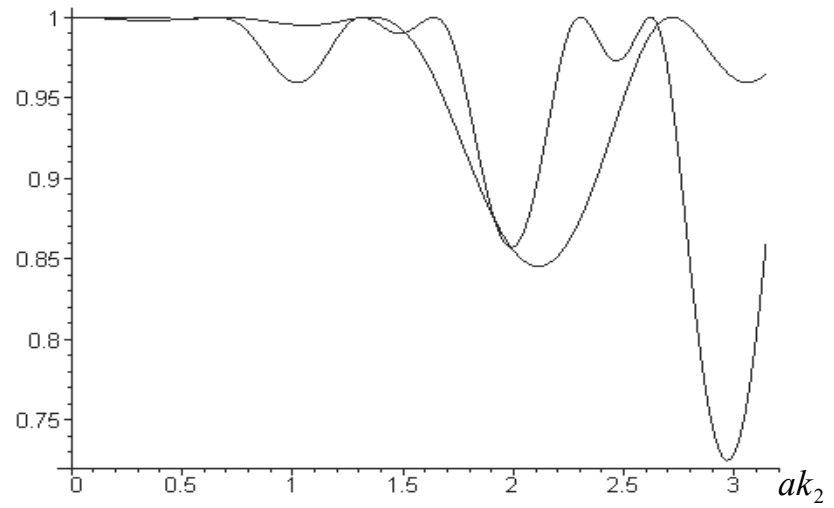

Fig.3. The transmission coefficient versus frequency parameter for large $d$.

For fixed $a k_{1}$ and $D$ the module of the reflection coefficient $|R|$ for the relative parameter $b / a$ has a different pattern of behaviour. It is a monotonically increasing function $\left(a k_{1}=1\right)$, such a property is observed after some critical value of the disclosure $b=0.76$ (Fig. 4).

$|R|$

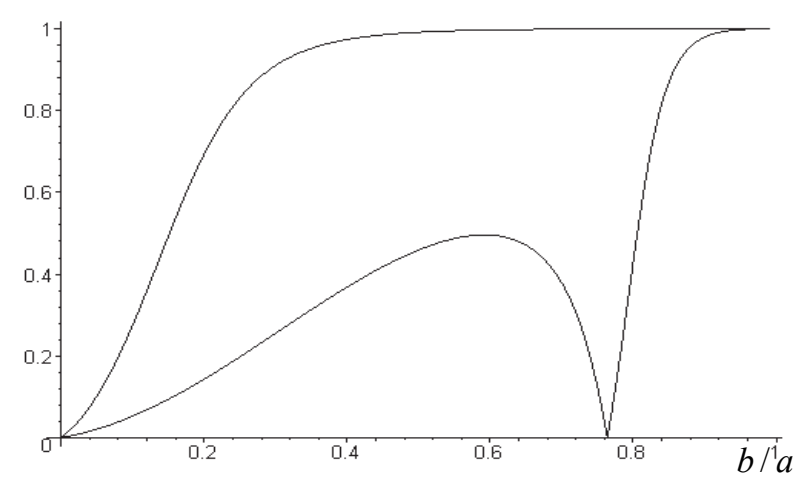

Fig. 4. The reflection coefficient versus relative crack's size.

If $b / a$ and $a k_{1}$ are fixed, then the maximum reflection occurs for the greatest cracks in the material. Conversely, a weak reflection occurs for small cracks, which is quite natural from a physical point of view. Also it turns out that the reflection coefficient $|R(D)|$ for each value $b / a$ can reach its maximum, while there are such distances $D$, when the process of passing is absolute (Fig. 5, where $b=0.45$ ).

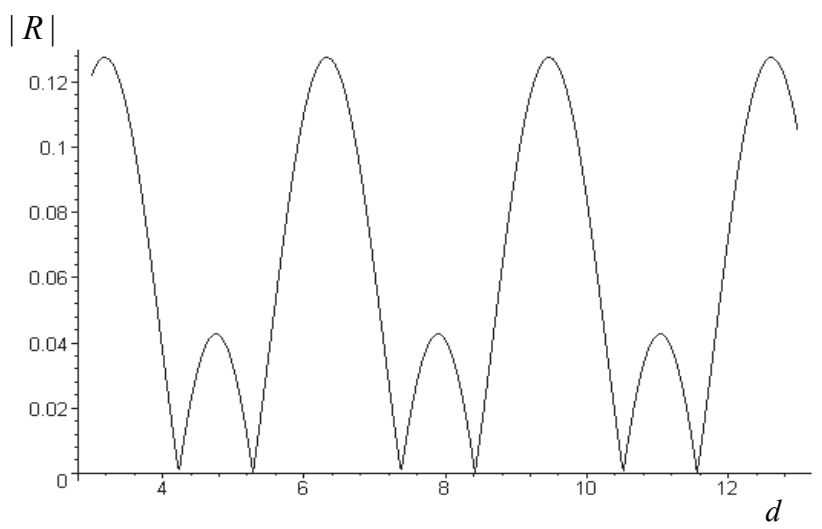

Fig. 5. The reflection coefficient versus parameter $d$.

The method developed in this research allows to efficiently explore a more complex wave problem, where a vertical array containing the studied periodic system of cracks is consistently and periodically repeated (more than 3 screens) along the direction of wave propagation [11]. In this case threefold-periodic array of cracks will be the subject of future studies where it is expected to obtain some new specific properties of waves in solid media, as it was for acoustic filters [10].

\section{REFERENCES}

[1] J. D. Achenbach and Z. L. Li, "Reflexion and transmission of scalar waves by a periodic array of screens," Wave Motion, vol. 8, issue 3, pp. 225-234, 1986. https://doi.org/10.1016/S0165-2125(86)80045-2

[2] J. W. Miles, "On Rayleigh scattering by a grating," Wave Motion, vol. 4, issue 3, pp. 285-292, 1982. https://doi.org/10.1016/0165-2125(82)90024-5

[3] E. Scarpetta and M. A. Sumbatyan, "Explicit analytical results for onemode oblique penetration into a periodic array of screens," IMA Journal of Applied Mathematics, vol. 56, issue 2, pp. 109-120, 1996. https://doi.org/10.1093/imamat/56.2.109

[4] E. Scarpetta and M. A. Sumbatyan, "On wave propagation in elasticsolids with a doubly periodic array of cracks," Wave Motion, vol. 25, issue 1, pp. 61-72, 1997. https://doi.org/10.1016/S0165-2125(96)00033-9

[5] E. Scarpetta and V. Tibullo, "On the three-dimensionl wave propagation through cascading screens having a periodic system of arbitrary openings," Int. J. Eng. Sci., vol. 46, issue 2, pp. 105-111, 2008. https://doi.org/10.1016/j.ijengsci.2007.10.004

[6] D. Homentcovschi, R. N. Miles and Lin Tan, "Influence of viscosity on the diffraction of sound by a periodic array of screens. J. Acoust. Soc. Am., vol. 117, issue 5, pp. 2761-2771, 2005. https://doi.org/10.1121/1.1882923

[7] E. L. Shenderov, "Propagation of sound through a screen of arbitrary wave thickness with gaps," Soviet Phys. Acoust., vol. 16, issue 1, pp. 115-131, 1970.

[8] S. M. Belotserkovsky and I. K. Lifanov, Method of Discrete Vortices, CRC Press: Boca Raton, Florida, 1992.

[9] I. N. Sneddon and M. Lowengrub, Crack Problems in the Classical Theory of Elasticity, Wiley: London, 1969.

[10] Z. Liu, X. Zhang, Y. Mao, Y. Y. Zhu, Z. Yang, C. T. Chan, and P. Sheng, "Locally resonant sonic materials," Science, vol. 289, Vol. 5485 pp. 1734-1736, 2000.

https://doi.org/10.1126/science.289.5485.1734

[11] M. Yu. Remizov and M. A. Sumbatyan, "Low frequency penetration of elastic waves through a triple periodic array of cracks", in Advanced Materials. Manufacturing, Physics, Mechanics and Applications, vol. 175 (Springer Proceedings in Physics) Springer International Publishing, pp. 459-474, 2016.

https://doi.org/10.1007/978-3-319-26324-3 32 


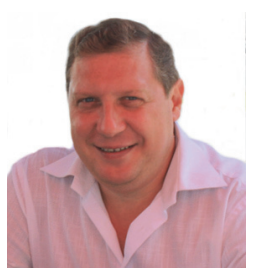

Remizov, Michael Yu., obtained the Ph.D. degree in Physics and Mathematics in 2003 from Southern Federal University, Rostov-on-Don, Russia. The theme of his Ph.D. thesis was "Energy Fields Analysis in Composed Anisotropic Half-Plane".

Currently he is an Associate Professor with the Department of Technical Mechanics, Rostov-on-Don Civil Engineering University,
His major areas of scientific activities are elasticity theory of half-infinite anisotropic composed media, theory of physical diffractions for periodic systems. He is author of about 30 papers published in scientific journals and presented at international and Russian scientific conferences.

E-mail: remizov72@mail.ru

2D zemas frekvences elastīgo viḷnu iekḷūšana caur dubultu periodisku plaisu masīvu Michael Remizovs

Rostovas Valsts Būvniecības inženierżinātṇu universitāte, Krievija

Raksts ir veltîts atstarošanas un pārvades koeficientu aprēḳiniem, kad plaknes vilnis mijiedarbojas ar divdimensiju režği, kuru veido periodisks taisnstūrveida spraugu masīvs elastīgā materiālā. Pie uzdotas frekvences uzdevums tiek novests uz integrālvienādojumu sistēmu, kas tiek rēḳināta dažādiem spraugu izmēriem, lai iegūtu precīzu viḷnu lauku spraugu struktūras iekšienē. Elastīgu viḷnu izplatīšanās pētījumi caur periodiskiem režğiem ir svarīgs uzdevums daudzos praktiskos lietojumos: mehānikā, akustikā, elektromagnētismā. Analītiski rezultāti var tikt iegūti gadījumā, ja frekvences ir zemas un mijiedarbības režīms ir vājš. Šādā gadījumā daži aptuveni rezultāti var tikt iegūti analītiskā formā [1]-[10]. Iepriekšējā rakstā mēs pētījām elastīgu viḷ,nu izplatišanos plaknē ar bezgalīgu periodisku spraugu skaitu [11]. Šis raksts turpina dotās problēmas pētīšanu triju plakṇu gadījumā. Viḷnu izplatīšanās process un visi fizikālie lielumi ir laikā harmoniski. Tāpat kā darbā [7] tiek izmantoti šādi pieṇēmumi: (a) ir apskatīta tikai vienas frekvences viḷnu izplatî̌sanās, (b) vertikālās plaknes ar spraugām ir būtiskā attālumā viena no otras. Tagadējā darba mērḳis ir vispārināt iepriekš iegūtos precīzos rezultātus, lietojot tos paralēlu plakṇu kopai ar dubultperiodisku šauru spraugu kopu. Tas tiek izdarīts, izmantojot singulāra integrālvienādojuma kodola īpašības.

Atslēgas vārdi - Atstarošanas un pārvades koeficients, divdimensiju režğis, fiksētas frekvences aproksimācija, singulars integrālvienādojums. 